\title{
Occurrence of anti-Neospora caninum antibodies in sheep from farms located in northern Parana, Brazil
}

\section{Ocorrência de anticorpos contra Neospora caninum em ovelhas de propriedades rurais no norte do Paraná, Brasil}

\author{
Kenio Ferreira Munhóz'; Mario de Luca Neto ${ }^{4}$; Sérgio Mangano de Almeida \\ Santos $^{4}$; João Luis Garcia ${ }^{2}$; José da Silva Guimarães Junior²; Odilon Vidotto²; \\ Selwyn Arlington Headley ${ }^{3}$; Milton Hissashi Yamamura ${ }^{2 *}$
}

\begin{abstract}
The protozoan Neospora caninum is the cause of reproductive diseases in some species of domestic animals that results in severe economic losses to livestock production. These diseases might be transmitted by infected females to their offspring or from oocysts eliminated within the feces of the definitive hosts. The objective of this study was to determine the occurrence of serum antibodies of $N$. caninum in sheep maintained on farms located in northern Paraná, Brazil. Serum samples were obtained from 381 sheep and 25 dogs that were maintained in 11 farming units to detect the presence of anti- $N$. caninum antibodies by using the indirect immunofluorescence assay (IFA); titers of antibodies that were $\geq 50$ were considered as positive. The results from this study demonstrated that $13.91 \%$ of sheep $(10.7 \%$ $<$ CI $0.95 \%<17.9 \%)$ and $36 \%(18.7 \%<$ CI $0.95 \%<57.4 \%)$ of dogs were seropositive to $N$. caninum. Further, significant differences were observed when the association between the serology results of sheep and two variables were compared: the slaughter of animals within these units $(\mathrm{P}=0.0041$; OR $=5.27)$ and the access of dogs to the viscera of slaughtered animals $(\mathrm{P}=0.0001 ; \mathrm{OR}=1.49)$. These results confirmed the epidemiological importance of the domestic dog relative to the dissemination and maintenance of $N$. caninum with an environment.
\end{abstract}

Key words: Neospora caninum, sheep, dogs, indirect immunofluorescence assay, serum-occurrence

\section{Resumo}

Neospora caninum é um protozoário causador de doença de esfera reprodutiva em algumas espécies de animais, causando perdas econômicas em rebanhos de produção. Esta doença está ligada diretamente a problemas reprodutivos, podendo ser transmitida por fêmeas infectadas aos seus descendentes ou através de oocistos eliminados nas fezes de seus hospedeiros definitivos. O objetivo deste trabalho foi estimar a soro-ocorrência de anticorpos contra N.caninum em ovinos de propriedades rurais localizadas no norte do Paraná. Foram colhidas 381 amostras de sangue de ovelhas e 25 amostras de sangue canino de 11 propriedades rurais na região norte do estado do Paraná. Utilizou-se a reação de imunofluorescência indireta (RIFI) para a detecção de anticorpos contra N.caninum e foram considerados positivos os animais que apresentaram títulos $\geq 50$. Encontrou-se uma ocorrência de 13,91\% (10,7\% < IC 0,95\%< $17,9 \%)$ e $36 \%(18,7 \%<$ IC $0,95 \%<57,4 \%)$ de anticorpos contra $N$. caninum nos ovinos e nos cães,

\footnotetext{
${ }^{1}$ Mestre pelo Programa de Pós-Graduação em Ciência Animal, Universidade Estadual de Londrina, UEL. E-mail: keniofm@gmail. com.br

${ }^{2}$ Departamento de Medicina Veterinária Preventiva, Universidade Estadual de Londrina, Campus Universitário, Caixa Postal 6001, e-mail: jlgarcia@uel.br; jsgj@uel.br; vidotto@uel.br; yamamura@uel.br

${ }^{3}$ Department of Basic Veterinary Sciences, School of Veterinary Medicine, St. Matthew's University, Grand Cayman, Cayman Islands, British West Indies. E-mail: sheadley@smu.ky

${ }^{4}$ Alunos de graduação do Curso de Medicina Veterinária da Universidade Estadual de Londrina, UEL.

* Autor para correspondência
} 
respectivamente. Foi observada uma diferença significativa na associação entre o resultado da sorologia dos ovinos para N.caninum e as variáveis "abate animais na propriedade" $(\mathrm{P}=0,0041 ; \mathrm{OR}=5,27)$ e "cães com acesso às vísceras" $(\mathrm{P}=0,0001 ; \mathrm{OR}=1,49)$.

Palavras-chave: Neospora caninum, ovinos, cães, imunofluorescência indireta, soro-ocorrência

\section{Introduction}

Neospora caninum, a protozoan of the Phylum Apicomplexa, Family Sarcocystidae, subfamily Toxoplasmatinae (MUGRIDGE et al., 1999), is recognized as an important parasite of cattle, dogs, sheep, goats, horses, and cervids (BUXTON et al., 1997; DUBEY, 1999).

In sheep, natural and experimental infections have demonstrated the occurrence of vertical transmission and reproductive failures (HÃSSIG et al., 2003; WEST et al., 2006). This has resulted in death, embryo reabsorption, abortions, mummified fetus, neonatal deaths, and the births of fragile neonates or neonates that are physically healthy, but congenitally infected relative to the gestation stage of the adult sheep (HÃSSIG et al., 2003; BUXTON et al., 1997; MCALLISTER et al., 1996). Repetitive abortions, as have been described in cows, can also occur in sheep (JOLLEY et al., 1999). Cerebral neosporosis was detected in an adult Merino sheep from Australia suspected of dying with acute nonsuppurative meningoencephalitis and mild to moderate non-suppurative myelitis (BISHOP et al., 2010).

In 2003, the ovine herd of Brazil was estimated at 14.5 million (IBGE, 2009). During the 90s, the Brazilian sheep herd was 20 million, but due to retraction in commercial wool sales, there was reduction in the national herd. Currently, sheep rearing is expanding but with more emphasis on meat production. The South of Brazil contains $31.75 \%$ of the national sheep herd, being only second to the Northeast where $56.56 \%$ of the sheep reared in Brazil is located. In the state of Paraná, the ovine population consists of 601,704 animals, which are distributed throughout the State; this has resulted in an unstable supply of sheep for slaughter (IBGE, 2009).

Due to the fact that sheep production is in evolution in Brazil, particularly in the northern region of the state of Parana, studies of infections and parasitic diseases of great economic significance, such as neosporosis, are of extreme importance. Consequently, a serological survey was done due to the absence of information relative to the occurrence of circulating antibodies of $N$. caninum in rural proprieties located in the north of Parana.

\section{Material and Methods}

\section{Population and sampling methodology}

The region evaluated during this study has a subtropical temperate climate, which is characterized by an average temperature that is below $18^{\circ} \mathrm{C}$ during winter and above $22^{\circ} \mathrm{C}$ in summer, with rainy seasons that are not well defined. These climatic conditions are adequate for the maintenance of the oocysts of $N$. caninum within the environment; factors such as climate and relative humidity influence the sporulation of oocysts of $N$. caninum (SANDERSON; GAY; BASZLER, 2000).

During this study, 381 blood samples were obtained from sheep during November 2007 to January 2008. These sheep were from a population of 1,393 animals maintained in 11 rural farming units, which are located within six municipalities within the northern region of the state of Parana. Inclusion into this study was based on the rural properties being registered with the regional nucleus of the Secretaria da Agricultura Pecuária e Abastecimento of Londrina. The geographical locations of these regional units are shown in (Figure 1).

The sample size was determined by using the statistical program EPI-INFO-6.4 (DEAN et al., 1994); the estimated prevalence was $50 \%$, error $5 \%$, with a confidence interval (CI) of $95 \%$. Additionally, blood samples were collected from 25 dogs that were living within these areas (Table 1). 


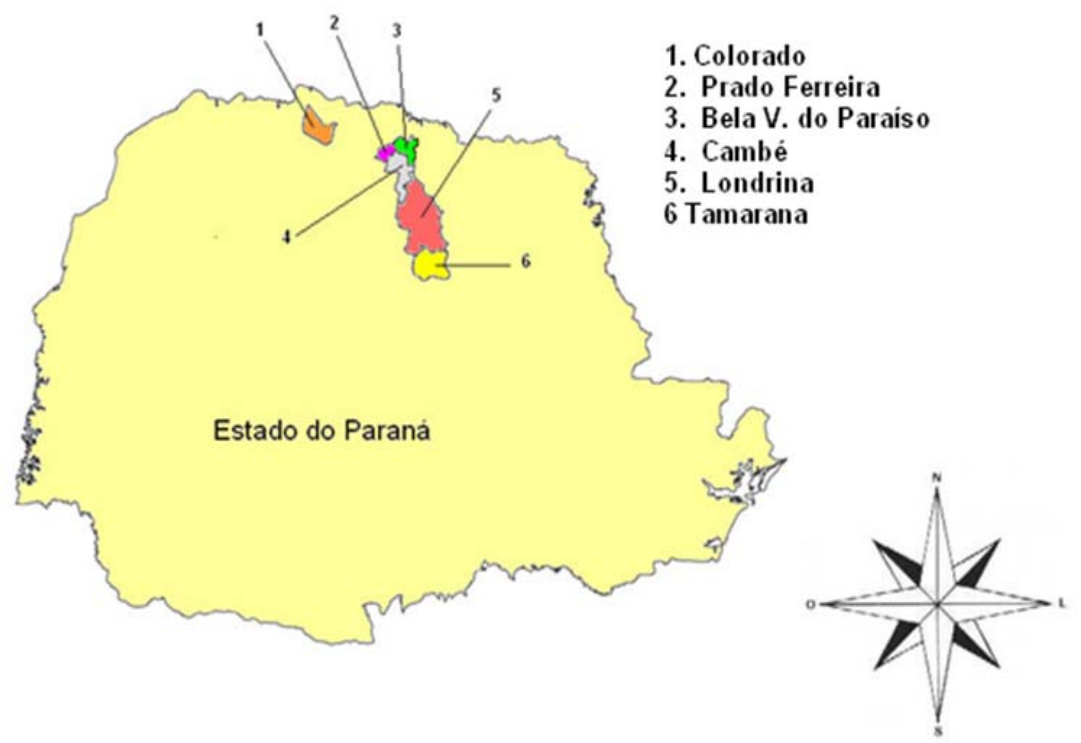

Figure 1. The geographical localization of the rural farming communities studied within the northern region of the state of Paraná.

Table 1. The serological occurrence of anti-Neospora caninum antibodies in sheep and dogs from rural farming units of northern Paraná.

\begin{tabular}{rccccc}
\hline \multicolumn{2}{c}{ Farming units } & \multicolumn{2}{c}{ № of sheep } & \multicolumn{2}{c}{ № of dogs } \\
\hline Code & $\begin{array}{c}\text { Total № } \\
\text { of animals }\end{array}$ & $\begin{array}{c}\text { Samples } \\
\text { analyzed }\end{array}$ & $\begin{array}{c}\text { Positive } \\
\text { Serum reactivity }(\%)^{\mathrm{a}}\end{array}$ & $\begin{array}{c}\text { Samples } \\
\text { analyzed }\end{array}$ & $\begin{array}{c}\text { Positive } \\
\text { Serum reactivity (\%) }\end{array}$ \\
\hline 1 & 180 & 31 & $0(0)$ & 2 & $0(0)$ \\
2 & 54 & 16 & $4(25)$ & 1 & $0(0)$ \\
3 & 83 & 15 & $2(13.3)$ & 1 & $0(0)$ \\
4 & 43 & 11 & $1(9.1)$ & 1 & $1(100)$ \\
5 & 380 & 102 & $4(3.9)$ & 4 & $0(0)$ \\
6 & 38 & 10 & $3(30)$ & 0 & $0(0)$ \\
7 & 45 & 10 & $0(0)$ & 2 & $0(0)$ \\
8 & 225 & 68 & $22(32.3)$ & 4 & $4(100)$ \\
9 & 38 & 15 & $3(20)$ & 2 & $0(50)$ \\
10 & 90 & 58 & $1(1.7)$ & 0 & $3(37.5)$ \\
11 & 217 & 45 & $13(28.9)$ & 8 & $9(36 \%)$ \\
\hline Total & 1393 & 381 & $53(13.91 \%)$ & 25 & \\
\hline
\end{tabular}

$\mathrm{a}=$ the occurrence of seropositivity is given in brackets. 


\section{Sample collection}

The samples from the dogs and sheep were collected by jugular venipuncture, after which these were placed in identifiable test tubes. The serum was obtained from each sample, then transferred to other tubes, and maintained at $-18^{\circ} \mathrm{C}$ until usage.

\section{Variables evaluated}

This study consisted of the collection of blood samples from sheep and dogs that were maintained within these farming units, as well as the analysis of an epidemiological questioner. The questioner investigated aspects related to the infectious agent, the presence or absence of dogs within all proprieties, the history of abortions of domestic animals, the management system employed, and the nutritional status of the animals. The owner or person responsible for each unit was interviewed.

\section{Serological evaluation}

All samples were evaluated by the indirect immunofluorescence assay (IFA) for the identification of anti- $N$. caninum IgG antibodies (CONRAD et al., 1993). Initially, all sera were screened at a dilution of 1:25 (JOLLEY et al., 1999; HELMICK et al., 2002). Those sera that demonstrated positive results were subjected to serial dilutions of 1:6400 for sheep, and 1:1600 for dogs. All slides were evaluated with the $40 \mathrm{x}$ eyepiece of an epifluorescence microscope. Samples with titer $\geq 50$ were considered as positive only when tachyzoites demonstrated total peripheral fluorescence (PARÉ; HIETALA; THURMOND, 1995).

\section{Statistical analyses}

The variables were analyzed by the Chi-square test using a significance level of $5 \%$, and by the exact Fisher Test. The possible associations were determined by using the program EpiInfo (version 6.04b; CDC-Atlanta), where $\mathrm{P} \leq 0.05$ was considered as significant.

\section{Results}

\section{Epidemiological survey}

Eleven properties were studied, and the size varied between 5 and 1300 hectares. In most $(54.5 \%, 6 / 11)$ of the farming units evaluated the principal commercial activity was animal rearing, while $45.4 \%$ practiced a mixture of animal rearing and crop production. All units were dedicated to sheep meat production, but $94.5 \%$ employed the semi-extensive productive system and only 5.5\% used only the extensive system. The total number of animals on each farm varied between 38 and 380 .

Most of the farming units $(72.7 \% ; 8 / 11)$ realized the slaughter of animals on their own grounds, while dogs were described as living in most units $(81.8 \%$; $9 / 11)$. From those units that had dogs, most $(72.7 \%)$ related that these animals were maintained free to roam, while only $27.3 \%$ indicated that the dogs were confined. Additionally, some units (27.3\%; $3 / 11$ ) reported other canids were maintained as pets. The average number of dogs per farming unit was 2.3, and this was observed in 9 of the 11 units investigated.

Within $27.3 \%$ (3/11) of the farming units the dogs maintained as pets received left-overs of human diets as food. Dogs from $63.7 \%(7 / 11)$ of the units were related as having access to the viscera of slaughtered animals.

All farming units related that there were abortions during the last 12 months. However, $26.8 \%$ of all abortions occurred during the first gestational trimester, with the majority $(66.7 \%)$ occurring during the last trimester. The frequency of reproductive problems that were related in most units $(75.6 \%)$ were described as occurring during the second and fifth breeding season; in $24.5 \%$ of the units the frequency was predominant during the first breeding season. 


\section{Serological evaluation}

During this study, 318 serum samples obtained from sheep were evaluated by the indirect immunofluorescence assay (IFA). From these, $13.91 \%$ (53/318) demonstrated a positive reaction to anti-N. caninum IgG antibodies (Table 1), having titers that were $>50(10.7 \%<\mathrm{CI} 0.95 \%<17.9 \%)$. Further, within four farming units ( $\#, 4,9$, and 11) there was the simultaneous identification of anti- $N$. caninum $\operatorname{IgG}$ antibodies in sheep and dogs; one of these units (\# 8), demonstrated the most elevated $(32.3 \%)$ occurrence of infection in sheep (Table 1). Additionally, serum samples from two units (\# 1 and 7) revealed negative results from all animals evaluated.
From all seropositive sheep, the titer with the greatest frequency (Table 2) was 200 (30.2\%), followed by $50(28.30 \%)$ and $100(18.90 \%)$; the most reduced frequency of titer observed was 6400 (1.9\%). Additionally, at least one sheep from $81.82 \%$ (9/11) of the units evaluated was serologically positive to antibodies of $N$. caninum; negative results were obtained from sheep that were maintained on $18.18 \%(2 / 11)$ of the faming units. From the 25 samples obtained from dogs that were living within these units, 36\% (9/25) reacted positive (Table 2) to antibodies of $N$. caninum by the IFA with titer $>50(18.7 \%<$ CI $0.95 \%<57.4 \%)$. The titer with the greatest frequency of seropositivity was 100 (33.4\%), followed by 200 and $400(22.2 \%)$; the lowest frequency was observed at a titer of 50 and $1600(11.1 \%)$.

Table 2. The distribution of seropositivity to Neospora caninum antibodies in sheep and dogs from rural areas of Northern Paraná.

\begin{tabular}{ccccc}
\hline \multirow{2}{*}{ Titer } & \multicolumn{2}{c}{ Sheep } & \multicolumn{2}{c}{ Dogs } \\
\cline { 2 - 5 } & № of positive samples & Occurrence (\%) & № of positive samples & Occurrence (\%) \\
\hline 50 & 15 & 28.3 & 1 & 11.2 \\
100 & 10 & 18.9 & 3 & 33.2 \\
200 & 16 & 30.2 & 2 & 22.2 \\
400 & 4 & 7.5 & 2 & 22.2 \\
800 & 3 & 5.7 & 1 & 11.2 \\
1600 & 2 & 3.8 & ND & ND \\
3200 & 2 & 3.8 & ND & ND \\
6400 & 1 & 1.9 & ND & ND \\
\hline Total & 53 & 100 & 9 & 100 \\
\hline
\end{tabular}

ND $=$ Not Determined

A significant statistical difference was observed between the association of seropositivity of $N$. caninum in sheep and two variables: the slaughter of animals within the rural units $(\mathrm{P}=0.0041 ; \mathrm{OR}=5.27)$ and dogs with access to the viscera of slaughtered sheep $(\mathrm{P}=0.0001 ; \mathrm{OR}=1.49)$.

\section{Discussion}

This is the first study epidemiological done with sheep maintained in rural properties in the north of Paraná. The seropositivity (13.91\%) observed in sheep from this region during this study was higher than previously described when compared to sheep (9.5\%) from the Midwest region of Paraná (ROMANELLI, 2002). When these results were 
compared to those described in other states of Brazil, there was marked differences in the prevalence reported. Reduced prevalence levels were obtained from serological studies done in the states of São Paulo, 9.2\% (FIGLIUOLO et al., 2004); Bahia, 7.4\% (OTERO et al., 2002); Rio Grande do Sul, $3.2 \%$ (VOGEL; ARENHART; BAUERMANN, 2006); Federal District, 8.8\% (UENO et al., 2009); Rio Grande do Norte, 1.8\% (SOARES et al., 2009); and Minas Gerais, 8.1\% (SALABERRY et al., 2010). However, greater prevalence values were reported in the state of Rondônia, 29\% (AGUIAR et al., 2004). Further, studies done in the United Kingdom (HELMICK et al., 2002) revealed a lower prevalence of only $0.45 \%$ (3/660) while the values (12\%) obtained from the Czech Republic (BARTOVÁ; SEDLÁK; LITERÁK, 2008) were relatively similar to those described in this study. For the differences observed in several serological evaluations be easily compared, the cut-off point in each study must be known; since each study utilized different cut-off points the sensibility and specificity of each evaluation will be affected (BJÖRKMAN; UGGLA, 1999), making the interpretation of these results difficult. Further, the serological results can be a manifestation of the production system of each study. During this study, $81.82 \%(9 / 11)$ of the farming units demonstrated positive seroreactivity to $N$. caninum, while $86.6 \%$ of 30 farms evaluated in São Paulo were seropositive (FIGLIUOLO et al., 2004). A closer examination of these studies revealed that the farms located in the state of São Paulo utilized advanced technological and commercial practices with high productivity livestock, while those of this study consisted of animals reared for domestic consumption with low productivity livestock. These productivity-related factors might be associated with the differences observed in these manuscripts.

Data from this study suggests that $N$. caninum is disseminated within the sheep population of the investigated geographical area, with occurrence varying between 1.7 to $32.3 \%$. Additionally, domestic dogs were present in most $(9 / 11)$ of the rural farming units investigated, and the propriety (unit \# 8) in which more than one dog was seropositive demonstrated the most elevated prevalence $(32.3 \%)$ of disease in sheep. This dogsheep association is of extreme importance for the transmission of neosporosis, since the domestic dog is the natural definitive host of this pathogen, and consequently responsible for its maintenance within these units via horizontal transmission to susceptible animal populations. However, in other units where the domestic dogs were maintained there was no serological manifestation of disease. The absence of disease in these areas might be related to the presence of other natural host of the pathogen within these farming units, since in some units other canids were observed but were not included within this study. The most frequently occurring titers $(200,50$, and 100) were observed in these areas; similar results have been described (FIGLIUOLO et al., 2004; SALABERRY et al., 2010).

During this study, only four rural units had dogs that were seropositive to $N$. caninum, while in two units neither the sheep nor dogs evaluated demonstrated positive reactivity. Further, in three units were sheep reacted positively to $N$. caninum, all dogs evaluated within these units revealed negative serological response. This is highly suggestive of vertical transmission of the parasite of the sheep that were maintained within these units (BUXTON et al., 1997), notwithstanding the frequent permanence of stray dogs from adjacent villages or the city of Londrina, within these rural herds.

Significant statistical differences were observed when the association between the serological results of sheep and the slaughter of animals ( $\mathrm{P}=0.0041$; $\mathrm{OR}=5.27)$ within these units and the free access of dogs to viscera of slaughtered sheep ( $\mathrm{P}=0.0001$; $\mathrm{OR}=1.49$ ) was compared. Similar results were described in Uberlândia, Minas Gerais in a study of urban, peri-urban, and rural dogs that revealed a greater occurrence of anti- $N$. caninum antibodies in rural dogs relative to their urban or peri-urban counterparts (FERNANDES et al., 2002); these 
authors attributed this finding to the presence of cattle within the rural areas, and the possibility of dogs ingesting parts/remains of placenta or aborted foetuses. Consequently, the findings of this and the study realized in Minas Gerais reinforced the epidemiological importance of the domestic dog relative to the transmission and maintenance of this agent, and suggest the need for additional epidemiological studies to evaluate the association between sheep and dogs. Further, this study has demonstrated that the rural farming unit with the highest occurrence $(32.3 \%)$ of circulating anti- $N$. caninum antibodies in sheep also had a corresponding elevated (100\%) seropositivity in dogs.

The principal method of dissemination of neosporosis in cows is via vertical transmission, i.e., females that have survived a congenital infection perpetuate the parasite during their entire lives, resulting in transmission to their neonates (BARTELS; WOUDA; SCHUKKEN, 1999; ANDERSON; ANDRIANARIVO; CONRAD, 2000). Although significant statistical differences $(\mathrm{P}=0.059 ; \mathrm{OR}=3.36)$ were not observed when the presence of dogs and the occurrence of $N$. caninum in sheep was compared, the occurrence of seropositive dogs within these proprieties must not be overlooked or ignored, as a possible form of horizontal transmission. Other studies have also demonstrated no statistical association between seropositivity and the presence of animals within the investigated region ((FIGLIUOLO et al., 2004).

During this study, there was no association between the serological results of $N$. caninum and several variables: the size of the propriety $(\mathrm{P}=0.0001)$; rearing system employed $(\mathrm{P}=0.20)$; frequency of reproductive problems $(\mathrm{P}=0.84)$; and the gestational phase of the affected animal $(\mathrm{P}=0.0011)$; similar results were described in a study realized in Texas with beef cattle (BARLING et al., 2001). Although most of the farming units (9/11) had an average of more than 2.3 dogs per unit, no statistical association was observed when the presence of dogs on any unit $(\mathrm{P}=0.059)$ with the method of breeding ( $\mathrm{P}=0.81)$ and the simultaneous presence of other canids $(\mathrm{P}=0.156)$ was compared. Similar results occurred in a study done in Brasília with sheep (UENO et al., 2009). These findings probably suggest that these variables are not of significant epidemiological importance in the dissemination and/or maintenance of $N$. caninum within a specific environment.

\section{References}

AGUIAR, D. M.; CHIEBAO, D. P.; RODRIGUES, A. A. R.; CAVAlCANTE, G. T.; LABRUNA, M. B.; GENNARI, S. M. Prevalência de anticorpos antiNeospora caninum em ovinos do município de Monte Negro, RO, Amazônia Ocidental brasileira. Arquivos do Instituto Biológico, São Paulo, v. 71, p. 616-618, 2004.

ANDERSON, M. L.; ANDRIANARIVO, A. G.; CONRAD, P. A. Neosporosis in cattle. Animal Reproduction Science, v. 60/61, p. 417-431, 2000.

BARLING, K. S.; McNEILL, J. W.; PASCHAL, J. C.; McCOLLUM III, F. T.; CRAIG, T. M.; ADAMS, L. G.; THOMPSON, J.A. Ranch management factors associated with antibody seropositivity for Neospora caninum in consignments of beef calves in Texas, USA. Preventive Veterinary Medicine, Amsterdam, Netherlands, v. 52, n. 1, p. 53-61, 2001.

BARTELS, C. J. M.; WOUDA, W.; SCHUKKEN, Y. H. Risk factors for Neospora caninum associted abortion storms in dairy herds in The Netherlands (1995 to 1997). Theriogenology, Stoneham, MA, v. 52, n. 2, p. 247-257, 1999.

BARTOVÁ, E.; SEDLÁK, K.; LITERÁK, I. Toxoplasma gondii and Neospora caninum antibodies in sheep in the Czech Republic. University of Veterinary and Pharmaceutical Sciences, Palacke'ho 1/3, 61242 Brno, Czech Republic. Veterinary Parasitology, Amsterdam, v. 161, p. 131-132, 2008.

BISHOP, S.; KING, J.; WINDSOR, P.; REICHEL, M. P.; ELLIS, J.; SLAPETA J. The first report of ovine cerebral neosporosis and evaluation of Neospora caninum prevalence in sheep in New South Wales. Veterinary Parasitology, Amsterdam, v. 170, n. 1/2, p. 137-142, 2010.

BJÖRKMAN, C.; UGGLA, A. Serological diagnosis of Neospora caninum infection. International Journal for Parasitology, v. 29, n. 10, p. 1497-1507, 1999. 
BUXTON, D.; MALEY, S. W.; THOMSON, K. M.;TREES, A. J.; INNES, E. A. Experimental infection of non-pregnant and pregnant sheep with Neospora caninum. Journal of Comparative Pathology, London, v. 117, n. 1, p. 1-16, 1997.

CONRAD, P. A.; BARR, B. C.; SVERLOW, K. W.; ANDERSON, M.; DAFT, B.; KINDE, H.; DUBEY, J. P.; MUNSON, L.; ARDANS, A. In vitro isolation and characterization of a Neospora sp. From aborted bovine fetuses. Parasitology, v. 106, n. 3, p. 239-249, 1993.

DEAN, G. A.; DEAN, A. J.; COULOMBIER, D.; BRENDEL, K. A.; SMITH, D. C.; BURTON, A. H.; DICKER, R. C.; SULIVAN, K. M.; FAGAN, R. F.; ARNER, T. G. Epi Info, Version 6: a word processing, database, and statistic program for epidemiology on microcomputers. Atlanta: Center for Diseases Control and Prevention, 1994.

DUBEY, J. P. Recent advances in Neospora and neosporosis. Veterinary Parasitology, Amsterdam, v. 84, n. 3/4, p. 349-367, 1999.

FERNANDES, B. C. T. M.; GENNARI, S. M.; SOUZA, S. L. P.; CARVALHO, J.; OLIVEIRA, W. G. O.; CURY, M. C. Frequência de anticorpos anti-N.caninum em cães das áreas urbana, periurbana e rural da região do Triângulo Mineiro, Minas Gerais, Brasil. In: CONGRESSO BRASILEIRO DE PARASITOLOGIA VETERINÁRIA, 12., 2002, Rio de Janeiro. Anais... Rio de Janeiro: Colégio Brasileiro de Parasitologia Veterinária, 2002. CD-ROM.

FIGLIUOLO, L. P. C.; KASAI, N.; RAGOZO, A. M. A.; PAULA, V. S. O.; DIAS, R. A.; SOUZA, S. L. P.; GENNARI, S. M. Prevalence of anti-Toxoplasma gongii and anti- Neospora caninum antibodies in ovine from São Paulo State, Brazil. Veterinary Parasitology, Amsterdam, v. 123, n. 3/4, p. 161-166, 2004.

HÃSSIG, M.; SAGER, H.; REITT, K.; ZIEGLER, D.; STRABEL, D.; GOTTSTEIN, B. Neospora caninum in sheep: a herd case report. Veterinary Parasitology, Amsterdam, v. 117, n. 3, p. 213-220, 2003.

HELMICK, B.; OTTER, A.; MCGARRY, J.; BUXTON, D. Serological investigation of aborted sheep and pigs for infection by Neospora caninum. Research in Veterinary Science, v. 73, n. 2, p. 187-189, 2002.

IBGE - The Brazilian Institute of Geography and Statistics. Banco de dados agregados. Available at: $<$ http://www.sidra.ibge.gov.br/bda/pecua/default.asp.>. Accessed on: 05 jan. 2009.

JOLLEY, W. R.; MCALLISTER, M. M.; MCGUIRE, A. M.; WILLS, R. A. Repetitive abortion in Neosporainfected ewes. Veterinary Parasitology, Amsterdam, v. 82, n. 3, p. 251-257, 1999.
MCALLISTER, M. M.; MCGUIRE, A. M.; JOLLEY, W. R.; LINDSAY, D. S.; TREES, A. J.; STOBART, R. $H$. Experimental neosporosis in pregnant ewes and their offspring. Veterinary Pathology, Amsterdam, v. 33, n. 6, p. 647-655, 1996.

MUGRIDGE, N. B.; MORRISON, D. A.; HECKEROTH, A. R.; JOHNSON, A. M.; TENTER, A. M. Phylogenetic analysis based on full-length large subunit ribosomal RNA gene sequence comparison reveals that $N$. caninum is more closely related to Hammondia heydorni than to Toxoplasma gondii. International Journal for Parasitology, Darwin, v. 29, n. 10, p. 1545-1556, 1999.

OTERO, A. R. S.; JESUS, E. E. V.; SILVA, V. M. G. da; GONDIM, L. F. P.; ALMEIDA, M. A. O. Evidência sorológica da infecção de ovinos por Neospora caninum no Estado da Bahia, Brasil. In: CONGRESSO BRASILEIRO DE PARASITOLOGIA VETERINÁRIA, 12., 2002, Rio de Janeiro. Anais ... Rio de Janeiro: Colégio Brasileiro de Parasitologia Veterinária. CD-ROM.

PARÉ, J.; HIETALA, S. K.; THURMOND, M. C. Interpretation of an indirect fluorescent antibody test for diagnosis of Neospora sp. infection in cattle. Journal of Veterinary Diagnostic Investigation, Columbia, v. 7, p. 273-275, 1995.

ROMANELLI, P. R. Avaliação soroepidemiológica de Neospora caninum e Toxoplasma gondii em ovinos do município de Guarapuava-Paraná. 2002 Dissertação (Mestrado em Sanidade Animal) - Faculdade de Medicina Veterinária. Universidade Estadual de Londrina, Paraná, 2002.

SALABERRY, S. R. S.; OKUDA, L. R.; NASSAR, A. F. C.; CASTRO, J. R. de; LIMA-RIBEIRO, A. M. C. Prevalence of Neospora caninum antibodies in sheep flocks of Uberlândia county, MG. Rev. Brasil. de Parasitol. Veterinária, São Carlos, v.19, n. 3, p. 148-151, 2010.

SANDERSON, M. W.; GAY, J. M.; BASZLER, T. V. Neospora caninum seroprevalence and associated risk factors in beef cattle in the northwestern United States. Veterinary Parasitology, Amsterdam, v. 90, n. 1/2, p. 15-24, 2000.

SOARES, H. S.; AHID, S. M. M.; BEZERRA, A. C. D. S.; PENA, H. F. J.; DIAS, R. A.; GENNARI, S. M. Prevalence of anti-Toxoplasma gondii and anti-Neospora caninum antibodies in sheep from Mossoro, Rio Grande do Norte, Brazil. Veterinary Parasitology, Amsterdam, v. 160, p.211-214, 2009. 
UENO, T. E. H.; GONÇALVES, V. S. P.; HEINEMANN, M. B.; DILLI, T. L. B.; AKIMOTO, B. M.; SOUZA, S. L. P.; GENNARI, S. M.; SOARES, R. M. Prevalence of Toxoplasma gondii and Neospora caninum infections in sheep from Federal District, central region of Brazil. Trop. Animal Health Prod., London, v. 41, n. 4, p. 547552, 2009.

VOGEL, F. S. F.; ARENHART, S.; BAUERMANN, F. V. Anticorpos anti-Neospora caninum em bovinos, ovinos e bubalinos no Estado do Rio Grande do Sul, Brasil. Ciência Rural, Santa Maria, v. 36, n. 6, p. 1948-1951, 2006.
WEST, D.; POMROY, W.; COLLETT, M.; HILL, F.; RIDLER, A.; KENYON, P.; MORRIS, S.; PATTISON, R. A possible role for Neospora caninum in ovine abortion in New Zealand. Small Ruminant Research, v. 62, n. 1/2, p. 135-138, 2006.

YAMANE, I.; KOKUHO, T.; SHIMURA, K.; ETO, M.; SHIBAHARA, T.; HARITANI, M.; OUCHI, Y.; SVERLOW, K.; CONRAD, P. A. In Vitro isolation and characterization of bovine Neospora species in Japan. Research in Veterinary Science, v. 63, n. 1, p. 77-80, 1997. 
